\title{
МОДЕЛЮВАННЯ ІНФОРМАЦЙНОГО ОСВІТНЬОГО СЕРЕДОВИЩА У ПРОЦЕСІ ПІДГОТОВКИ МАЙБУТНІХ ФАХІВЦІВ ВИДАВНИЧО- ПОЛІГРАФІЧНОЇ ГАЛУЗІ ДО ФОРМУВАННЯ МЕДІАПРОСТОРУ
}

\author{
Дяченко М. Д. \\ доктор педагогічних наук, дочент, \\ професор кафедри освіти та управління навчальним закладом \\ Класичний приватний університет \\ вул. Жуковського, 70-Б, Запоріжжя, Украӥна \\ orcid.org/0000-0001-7250-1371 \\ m.d.dyachenko@gmail.com
}

\author{
Ключові слова: вища освіта, \\ інфографіка, інформачійне \\ освітне середовище, \\ майбутній фахівеиь \\ видавничо-поліграфічної \\ галузі, педагогічна умова, \\ професійна підготовка, \\ формування.
}

У статті висвітлено наукові погляди на професійну освіту майбутніх фахівців видавничо-поліграфічної галузі, розкрито значення інформаційного освітнього середовища як основної педагогічної умови підготовки їх до формування медіапростору. Зазначено, що видавничополіграфічна галузь $є$ одним із важливих чинників розвитку сучасного суспільства, соціально-економічним складником процесу розбудови держави та зміцнення іiї авторитету на міжнародній арені. Видавничополіграфічна галузь забезпечує особисті та виробничі потреби громадян у різноманітній видавничій продукції. Фахівці цієї сфери сприяють підвищенню культурно-освітнього рівня нації, вільному доступу кожної людини до загальнолюдських цінностей. Зауважується, що в галузі видавничо-поліграфічної справи спостерігається приналежність до трьох типів професій: «людина - людина», «людина - знакова система», «людина - художній образ». Підкреслюється, що основним об'єктом у діяльності будь-якого фахівця видавничо-поліграфічної справи $є$ поліграфічний виріб як продукт, який необхідно кваліфіковано підготувати з метою випуску, опублікування, успішного просування на ринок і задоволення потреб суспільства. Акцентується увага на тому, що проблема якісної професійної підготовки фахівців поліграфічного профілю в сучасних умовах зростання ролі інформації та інформаційнокомунікаційних технологій посідає особливе місце у професійній освіті. Вказано на розширення спектру поліграфічної продукції. Наголошується на тому, що однією із ключових педагогічних умов якісної професійної підготовки майбутніх фахівців видавничо-поліграфічної галузі $\epsilon$ створення інформаційного освітнього середовища. Сучасні інформаційні системи дають змогу інтегрувати освітні ресурси та засоби презентації навчального контенту 3 мультимедійними ефектами, що інтенсифікує процеси ознайомлення студентів із теоретичним матеріалом різними способами, дає змогу використовувати програмне забезпечення для виконання практичних (лабораторних) робіт, розроблення творчих проектів, інфографіки. Інтенсивний розвиток інформаційного суспільства посилюе вимоги до фахівців із видавничо-поліграфічної справи. Це зумовлює пошук нових шляхів і методів у їх професійній підготовці й відкриває перспективи для нових досліджень. 


\title{
MODELING OF THE INFORMATION EDUCATIONAL ENVIRONMENT IN THE PROCESS OF TRAINING OF THE PUBLISHING AND POLYGRAPHIC INDUSTRY'S FUTURE PROFESSIONALS TO THE FORMATION OF MEDIA SPACE
}

\author{
Diachenko M. D. \\ Doctor of Pedagogy, Associate Professor, \\ Professor at the Department of Education and Management of the Educational Institution \\ Classic Private University \\ Zhukovskoho str., 70-B, Zaporizhzhia, Ukraine \\ orcid.org/0000-0001-7250-1371 \\ m.d.dyachenko@gmail.com
}

Key words: higher education, infographics, information educational environment, future specialist of publishing and printing industry, pedagogical condition, professional training, formation.
The article highlights the scientific views on the professional education of future specialists in the publishing and printing industry, reveals the importance of information educational environment as the main pedagogical condition for their preparation for the formation of the media space. It is noted that the publishing and printing industry is one of the important factors in the development of modern society, the socio-economic component of the process of state building and strengthening its authority in the international arena. The publishing and printing industry provides personal and production needs of citizens in a variety of publishing products. Specialists in this field contribute to raising the cultural and educational level of the nation, free access of everyone to universal values. It is noted that in the field of publishing and printing there are three types of professions: "man - man", "man - sign system", "man - artistic image". It is emphasized that the main object in the activities of any specialist in publishing and printing is a printed product as a product that must be qualified to prepare, prepare, publish, successfully market and meet the needs of society. Emphasis is placed on the fact that the problem of high-quality professional training of printing specialists in modern conditions of growing role of information and information and communication technologies, occupies a special place in vocational education.

The expansion of the range of printing products is indicated. It is emphasized that one of the key pedagogical conditions for high-quality professional training of future specialists in the publishing and printing industry is the creation of an informational educational environment. Modern information systems allow to integrate educational resources and means of presentation of educational content with multimedia effects, which intensifies the processes of acquainting students with theoretical material in different ways, allows to use software to perform practical (laboratory) work, develop creative projects, infographics. Intensive development of the information society increases the requirements for specialists in publishing and printing. This leads to the search for new ways and methods in their training and opens up prospects for new research.
Одним із важливих чинників розвитку сучасного суспільства $є$ видавничо-поліграфічна галузь як соціально-економічний складник розбудови держави та зміцнення іiі авторитету на міжнародній арені, що забезпечує особисті та виробничі потреби громадян у різноманітній видавничій продукції. Окрім того, фахівці видавничо-поліграфічної галузі сприяють підвищенню культурно-освітнього рівня нації, вільному доступу кожної людини до загальнолюдських цінностей.
Мета статті: висвітлити наукові погляди на професійну освіту майбутніх фахівців видавничо-поліграфічної галузі, розкрити значення інформаційного освітнього середовища як основної педагогічної умови їх підготовки до формування медіапростору.

Питанням розвитку видавничо-поліграфічної галузі та підготовки майбутніх фахівців для професійної діяльності в ній присвячено наукові праці таких учених, як В. Аугустайтіс, В. Бебик, 
С. Денисенко, Б. Дурняк, М. Згуровський, В. Іванов, Я. Котляревський, Е. Лазаренко, С. Литунов, В. Мартинів, О. Мельников, О. Обухова, Я. Угрин, Л. Швайка, В. Шпак, А. Штангрет тощо.

Загалом порушеній проблемі приділено досить уваги, проте, як зауважує О. Пушкар, підготовка фахівців мультимедійних технологій як одного 3 напрямів галузі видавництва і поліграфії суттєво відрізняється i, на жаль, ще не досить досліджена вченими [8].

Професійна компетентність фахівця з видавничо-поліграфічної справи - особистісні можливості, завдяки яким фахівець має змогу ефективно реалізовувати завдання редакторського процесу; гармонійне поєднання теоретичних і практичних напрацювань, які необхідні для здійснення діяльності в цій сфері. У галузі видавничо-поліграфічної справи спостерігається приналежність до трьох типів професій: «людина - людина», «людина - знакова система», «людина - художній образ». Ця приналежність допомагає визначити діапазон особистісних характеристик, необхідних для фахівця, функції якого сьогодні дуже широкі.

Нині простежується суттєве розширення спектру поліграфічної продукції, що включає не лише книги, газети і журнали, а й плакати, афіші, листівки, банкноти, рекламу, візитівки, упаковку та етикетки. Водночас не лише змінюється обсяг друкованої продукції за іiї видами, призначенням, оформленням, а й спостерігається одночасне зниження накладів і підвищення якості та оперативності випуску [1].

Проблема якісної професійної підготовки фахівців поліграфічного профілю в сучасних умовах зростання ролі інформації і повсюдного домінування інформаційно-комунікаційних технологій посідає особливе місце серед проблем професійної освіти. Зумовлено це особливою соціокультурною роллю фахівців поліграфічного профілю в умовах інформаційного суспільства, що стрімко розвивається [7].

Оскільки суттєвою ознакою видавничо-поліграфічної галузі сьогодення $\epsilon$ широке впровадження високопродуктивних технологій, які грунтуються на найновіших досягненнях електроніки, комп'ютерної техніки, хімії, цифрової оптики, спектроскопії та інших галузей науки [3, с. 51], то однією із ключових педагогічних умов якісної професійної підготовки майбутніх фахівців видавничо-поліграфічної галузі $є$ створення інформаційного освітнього середовища. Сучасні інформаційні системи дають змогу інтегрувати освітні ресурси та засоби презентації навчального контенту 3 мультимедійними ефектами, що інтенсифікує процеси ознайомлення студентів із теоретичним матеріалом різними способами, дає змогу використовувати програмне забезпечення для виконання практичних (лабораторних) робіт, розроблення творчих проектів, інфографічного продукту.

3 метою модернізації освітнього середовища закладу вищої освіти здійснюється ідентифікація організаторів освітнього процесу, які забезпечують інфраструктуру освітнього процесу; розподіляються функції та обов'язки між ними, розробляються освітні та освітньо-професійні програми за спеціальностями, навчальні плани, навчально-методичні комплекси дисциплін тощо.

3 метою оновлення освітнього середовища професійної підготовки майбутніх фахівців видавничо-поліграфічної галузі впроваджуються системні інновації у ЗВО, забезпечується організація освітнього процесу на основі студентоцентризму; забезпечується належна інформаційна та електронна підтримка освітнього процесу тощо.

Для забезпечення ефективності інформаційного освітнього середовища створюється система підтримки навчальних програм (наприклад, на базі програмного комплексу Moodle як потужного чинника модернізації професійної освіти).

Загалом Moodle (Modular Object Oriented Dictance Learning Environment) $є$ системою управління навчальним контентом (LCMS - Learning Content Management Systems), завдяки якій можна створювати електронні навчальні курси для різних типів навчання, у тому числі змішаного та дистанційного. Автором концепції платформи e-learning Moodle $\epsilon$ австралієць М. Доугіамас, на думку якого, головне - створити систему, в якій враховувалися би педагогічні аспекти, що базуються на основах пізнавальної психології, коли студент є активним суб'єктом, який самостійно створює свою власну систему знань, користуючись доступними йому джерелами. При цьому роль викладача (тьютора) полягає в основному в мотивуванні і підтримці своїх підопічних шляхом підготовки завдань для самостійного опрацювання, оцінювання результатів їх виконання, коригування знань студентів. Згідно із засадами суспільного конструктивізму, конструйоване знання - найефективніше, коли студенти навчаються у взаємодії в групі, де можна поділитися своїми досвідом і думками та сприйняти, збагатитися досвідом і думками своїх одногрупників. Важливою характеристикою проекту Moodle виступає його web-сайт, який є централізованим джерелом відомостей про систему, а також місцем для дискусій та співпраці користувачів Moodle: системних адміністраторів, викладачів, дослідників, проектувальників і розробників [9].

Програмний комплекс Moodle має у своєму розпорядженні велике розмаїття програмних модулів, за допомогою яких можна організувати навчальну роботу студентів (Activity Modules - модулі 
діяльності). Кожен із цих модулів має відповідні дидактичні властивості, що дає змогу сформувати певний перелік навчально-методичних матеріалів націлених на вирішення студентом завдань дисципліни [там само].

Перевагою платформи e-learning Moodle, як зазначає В. Кравченко [5], є те, що програмне забезпечення платформи написано мовою РНР iз використанням безкоштовних загальнодоступних баз даних (MySQL, PostgreSQL). Платформу Moodle можна встановити на будь-яку операційну систему (MS Windows, Unix, Linux). Система Moodle відповідає всім основним критеріям, що висуваються до систем електронного навчання, зокрема таким, як: функціональність - наявність набору функцій різного рівня (форуми, чати, аналіз активності студентів, управління курсами та навчальними групами тощо); надійність - зручність адміністрування та управління навчанням, простота оновлення контенту на базі наявних шаблонів, захист користувачів від зовнішніх дій тощо; стабільність - високий рівень стійкості роботи системи стосовно різних режимів роботи та активності користувачів; вартість - сама система безкоштовна, витрати на ії впровадження, розроблення курсів і супровід - мінімальні; відсутність обмежень за кількістю ліцензій на слухачів (студентів), модульність - наявність у навчальних курсах набору блоків матеріалу, які можуть бути використані в інших курсах; наявність вбудованих засобів розроблення та редагування навчального контенту, інтеграції різноманітних освітніх матеріалів різного призначення; підтримка міжнародного стандарту SCORM (Sharable Content Object Reference Model) - основи обміну електронними курсами, що забезпечує перенесення ресурсів до інших систем; наявність системи перевірки та оцінювання знань слухачів у режимі онлайн [5].

Переваги інформаційного освітнього середовища полягають у тому, що студент може мати програмне забезпечення, що відповідає європейським стандартам 3 організації освітнього процесу; використовувати текстові, графічні, аудіо- та відеоматеріали; бути включеним до Європейського реєстру власників авторських курсів; мати розширений доступ до Internet-pecyрсів, можливість дистанційно опановувати навчальний матеріал, достроково складати заліково-екзаменаційну сесію тощо [9]. Для створення та підтримки такого інформаційного освітньо-професійного середовища необхідно вирішити комплекс проблем організаційного, технологічного та методичного супроводу освітнього процесу.

Використання в навчальному процесі новітніх інформаційно-комунікаційних технологій, використання комп'ютерів нових поколінь, створення умов для широкого використання можливостей
Інтернету дасть змогу не лише забезпечити підвищення змістовності навчального процесу, але й використовувати їх як засіб навчання і як робочий інструментарій майбутнього фахівця [1]. Впровадження IКТ у процес засвоєння студентами поліграфічного профілю фундаментальних знань має значний вплив і сприятиме швидкому професійному зростанню, оскільки ці технології дають можливість використання нових знань у професійній діяльності [12].

Як зауважують дослідники, в контексті інформаційного освітнього середовища актуальним $€$ : модернізація матеріальної поліграфічної бази навчальних закладів $[6 ; 11]$; видання навчальнометодичної літератури, створення методичного, інформаційно-консультаційного та програмного забезпечення [8]; формування сучасного довідково-інформаційного середовища для забезпечення студентів інноваційними, дидактичними, професійно-спеціалізованими матеріалами 3 використанням інформаційно-комунікаційних технологій [2; 12], тобто створення сучасного електронного освітнього середовища тощо.

Головними перевагами застосування системи електронної підтримки навчального процесу студентів є: надання їм повної інформації щодо їхньої професійної підготовки; надання студентам можливості вибору та проектування власної траєкторії засвоєння навчальних дисциплін (темпів і послідовності вивчення теоретичного матеріалу, виконання індивідуальних та контрольних завдань різного рівня складності); забезпечення викладачами педагогічного супроводу вивчення студентами навчальної дисципліни, комунікаційної взаємодії з ними та співпраці (онлайн-консультації, форуми, повідомлення через внутрішню електронну пошту віртуальної аудиторії) [5].

Модель ідеального процесу навчальної діяльності, на думку М. Федорової, може бути визначена як передача за мінімальний час необхідної кількості навчальної інформації від педагога до вихованця для подальшого його самостійного розвитку в напрямі певної мети, яка ним усвідомлюється та приймається [10, с. 61].

Висновки і пропозиції. Таким чином, професійні вимоги до сучасного фахівця з видавничо-поліграфічної справи спонукають до пошуку нових шляхів і методів у підготовці майбутніх фахівців, створення сприятливих умов для їх творчої самореалізації і формування професійної готовності до роботи у професійній сфері. Основним об'єктом у діяльності будь-якого фахівця видавничо-поліграфічної справи $\epsilon$ поліграфічний виріб як продукт, який треба кваліфіковано підготувати 3 метою випуску, опублікування, успішного просування на ринок і задоволення потреб суспільства. Важливою педагогічною умовою ефективної підготовки 
майбутніх фахівців видавничо-поліграфічної галузі до формування медіапростору є створення інформаційного освітнього середовища у закладі вищої освіти. Це сприяє інтеграції засобів презентації навчального контенту 3 мультимедійними ефектами, що інтенсифікує процеси ознайомлення студентів із теоретичним матеріалом різними способами, дає змогу використовувати програмне забезпечення для виконання практичних (лабораторних) робіт, розроблення творчих проектів, створення інфографіки. Наукова розвідка розкриває лише окремі аспекти порушеної проблеми, що відкриває перспективи для нових досліджень.

\section{ЛІТЕРАТУРА}

1. Боженко О.М. Підготовка фахівців для видавничо-поліграфічного комплексу в Українській академії друкарства: досягнення, проблеми, перспективи. Поліграфія і видавнича справа. 2002. № 39. C. $198-203$.

2. Величко О.М., Мамонов Ю.П. Впевнений поступ у майбутнє. Технологія і техніка друкарства. 2010. № 2. C. 208-212. URL: nbuv.gov.ua/UJRN/Titd_2010_2_34 (дата звернення: 15. 12. 2020).

3. Денисенко С.М. Професійна підготовка фахівців видавництва і поліграфії у ВНЗ: стан, проблеми, шляхи вдосконалення. Проблеми інженерно-педагогічної освіти. 2017. № 56-57. С. 49-57.

4. Котляревський Я. Удосконалення системи підготовки кадрів для видавничо-поліграфічної діяльності. Науковий вісник НЛТУ України : зб. наук.-техн. пр. 2014. Вип. 24.5. С. 384-389.

5. Кравченко В.М. Модернізація професійної підготовки викладачів вищої школи в умовах магістратури: теорія і практика : монографія. Запоріжжя : КПУ, 2016. 435 с.

6. Литунов С.Н., Обухова Е.Б. Анализ подготовки трудовых ресурсов для полиграфии в ОмПИ-ОмГТУ. Известия Тульского государственного университета. Технические науки. 2013. № 3. С. 214-222.

7. Матросова И.Г. Проблемы подготовки будущих специалистов полиграфического профиля в условиях информационного общества. Педагогический альманах. 2013. № 20. С. 123-129.

8. Пушкар О.І., Сергієнко О.В. Підготовка інноваційних фахівців спеціальності «Технології електронних мультимедійних видань». Проблеми інженерно-педагогічноїосвіти. 2013. № 40/41. С. 228-235.

9. Система електронного навчання BHЗ на базі MOODLE : методичний посібник / Ю.В. Триус, I.В. Герасименко, В.М. Франчук. Черкаси. 220 с.

10. Федорова М.А. Педагогическая синергетика как основа моделирования и реализации деятельности преподавателя высшей школы : дис. ... канд. пед. наук : 13.00.08. Ставрополь, 2004. 169 с.

11. Шпак В.І. Розвиток видавничої справи України в 1990-2010 pp. : автореф. дис. ... канд. іст. наук. : 07.00.01. Переяслав-Хмельницький, 2011. 20 с.

12. Юденкова О.П. Впровадження інформаційно-комунікаційних технологій як педагогічна умова підготовки кваліфікованих робітників для видавничо-поліграфічної галузі. Теорія $і$ методика електронного навчання. 2010. № 1. С. 256-262.

\section{REFERENCES}

1. Bozhenko O.M. (2002). Pidghotovka fakhivciv dlja vydavnycho-polighrafichnogho kompleksu v Ukrajinsjkij akademiji drukarstva: dosjaghnennja, problemy, perspektyvy [Training of specialists for the publishing and printing complex at the Ukrainian Academy of Printing: achievements, problems, prospects]. Printing and publishing. Vol. 39. P. 198-203 [in Ukrainian].

2. Velychko O.M., Mamonov Ju.P. (2010). Vpevnenyj postup u majbutnje [Confident progress into the future]. Printing technology and technique. Vol. 2. P. 208-212. URL: nbuv.gov.ua/UJRN/Titd_2010_2_34 (data zvernennja: 15.12.2020) [in Ukrainian].

3. Denysenko S.M. (2017). Profesijna pidghotovka fakhivciv vydavnyctva i polighrafiji u VNZ: stan, problemy, shljakhy vdoskonalennja [Professional training of publishing and printing specialists in universities: condition, problems, ways to improve]. Problems of engineering and pedagogical education. Vol. 56-57. P. 49-57 [in Ukrainian].

4. Kotljarevsjkyj Ja. (2014). Udoskonalennja systemy pidghotovky kadriv dlja vydavnycho-polighrafichnoji dijaljnosti [Improving the training system for publishing and printing activities]. Scientific Bulletin of NLTU of Ukraine. Vol. 24.5. P. 384-389 [in Ukrainian].

5. Kravchenko V.M. (2016). Modernizacija profesijnoji pidghotovky vykladachiv vyshhoji shkoly v umovakh maghistratury: teorija i praktyka : monoghrafija [Modernization of professional training of high school teachers in the conditions of master's degree: theory and practice: monograph]. Zaporizhzhja: KPU. 435 p. [in Ukrainian].

6. Lytunov S.N., Obukhova E.B. (2013). Analyz podghotovky trudovыkh resursov dlja polyghrafyy v OmPYOmGhTU [Analysis of the preparation of labor resources for printing in OmPI-OmSTU]. Proceedings of Tula State University. Technical sciences. Vol. 3. P. 214-222 [in Ukrainian]. 
7. Matrosova Y.Gh. (2013). Problemы podghotovky budushhykh specyalystov polyghrafycheskogho profylja $\mathrm{v}$ uslovyjakh ynformacyonnogho obshhestva [Problems of training future specialists of polygraphic profile in the conditions of information society]. Pedagogical almanac. Vol. 20. P. 123-129 [in Ukrainian].

8. Pushkar O.I., Serghijenko O.V. (2013). Pidghotovka innovacijnykh fakhivciv specialjnosti «Tekhnologhiji elektronnykh muljtymedijnykh vydanj» [Training of innovative specialists in the specialty "Technologies of electronic multimedia publications"]. Problems of engineering and pedagogical education. 2013. Vol. 40/41. P. 228-235 [in Ukrainian].

9. Systema elektronnogho navchannja VNZ na bazi MOODLE : metodychnyj posibnyk [MOODLE-based university e-learning system: a methodical manual] / Yu.V. Tryus, I.V. Gherasymenko, V.M. Franchuk. Cherkasy. 220 p. [in Ukrainian].

10. Fedorova M.A. (2004). Pedagogicheskaya sinergetika kak osnova modelirovaniya i realizatsii deyatel'nosti prepodavatelya vysshey shkoly [Pedagogical Synergetics as the Basis for Modeling and Implementation of the Activities of a Higher School Teacher] : dis. ... kand. ped. nauk : 13.00.08. Stavropol. 169 p. [in Russian].

11. Shpak V.I. (2011). Rozvytok vydavnychoji spravy Ukrajiny v 1990-2010 rr. [Development of the publishing business of Ukraine in 1990-2010] : avtoref. dys. ... kand. ist. nauk. : 07.00.01. Perejaslav-Khmeljnycjkyj. 20 s. [in Ukrainian].

12. Judenkova O.P. (2010). Vprovadzhennja informacijno-komunikacijnykh tekhnologhij jak pedaghoghichna umova pidghotovky kvalifikovanykh robitnykiv dlja vydavnycho-polighrafichnoji ghaluzi [Introduction of information and communication technologies as a pedagogical condition for training skilled workers for the publishing and printing industry]. Theory and methods of e-learning. Vol. 1. P. 256-262 [in Ukrainian]. 